\title{
POLICY AND LEGISLATION FOR CULTURAL PROPERTY IN ITALY. THE FOUNDATION OF THE MINISTRY FOR CULTURAL AND ENVIRONMENTAL ASSETS 1974-1975
}

\author{
Andrea Ragusa*
}

\begin{abstract}
The topic of cultural assets is today the object of increasing interest on the part of the social sciences, and represents one of the most relevant aspects of public debate, both on a cultural and political level. However, the topic stills appears insufficiently considered, especially at a historical level, compared to the ample juridical scholarship and significant politological scholarship of Anglo-Saxon countries. In Italy, the field has been considered primarily in the most recent studies about current legislation, and with exception for several sporadic cases, less in terms of its historical evolution. The contribution herein proposed approaches the issue from a historical point of view, examining a particularly important moment in the Italian situation, that of the foundation of the Ministry for Cultural and Environmental Assets in 1974. This act appears as the point of arrival of the debate which evolved in Italy starting from the late 19th century and which continued for the entire 20th century, intersecting the aspects of transformations of institutions and of the administrative structure of the State. Furthermore, the debate involved the profound changes taking place in the society, especially during the 1950s and 1960s, as part of the industrial boom which arrived with the so-called "miracle". In placing under examination the archival documentation conserved at the section "Ministry for Cultural and Environmental Assets" of the Archives of Giovanni Spadolini-who was the promoter and soul of the Ministry, the essay proposes a reconstruction of the prerequisites and results of this important moment in Italian politics, drawing an outline of the structure that the Ministry acquired at the start.
\end{abstract}

INTRODUCTION

\footnotetext{
* Associate Professor of Contemporary History at the University of Siena, Director of the Interuniversity Centre for the History of Social Change and Innovation-University of Siena, member of the Editorial Board of the peer-review "Storia e Futuro" (www.storiaefuturo.eu). Research fields: History of Political Cultures in Europe; History of Political Communication; History of Politics for Cultural Heritage Management. He has devoted his interests of research to the matter of politics for cultural heritage management publishing a first book in 2011, Alle Origini Dello Stato Contemporaneo. Politiche di Gestione del Patrimonio Culturale ed Ambientale tra Ottocento e Novecento, (FrancoAngeli, Milano 2011), and a second in 2014, I Giardini Delle Muse. Il Patrimonio Culturale ed Ambientale in Italia Dalla Costituente All'istituzione del Ministero (1946-1975), (FrancoAngeli, Milano 2014). He is at the moment preparing a third book about politics for cultural heritage in a comparative approach.
} 
I. THE Foundation OF THE MinisTRY FOR CULTURAL AND ENVIRONMENTAL ASSETS: A POINT OF ARRIVAL, A TURNING POINT ...

II. THE Foundation OF THE MinistRY AND THE RolE OF GIOVANNI

SPADOLINI.

III. THE FOUNDATION OF THE MINISTRY FOR CULTURAL AND

ENVIRONMENTAL ASSETS: THE EXECUTIVE ORDER N ${ }^{\circ} 657$ OF 14 DECEMBER 1974

CONCLUSIONS . 243

\section{INTRODUCTION}

The issue of the management of cultural and environmental assets appears today to receive much less attention than the centrality of the problem merits, especially considering the importance of such assets in the social, political and institutional life of every nation. Just consider that, the attention towards questions of cultural assets, even in academic settings, comes primarily from scholars and research centers trained and oriented towards different thematic interests and methodological criteria.

In a general reconnaissance, three areas of research are most often examined by those scholars working in the fields of cultural and environmental assets.

The first of these, and certainly the most relevant from a quantitative point of view, is scholarship of a juridical nature, linked to the issue of identifying the actual application of normative rules for the field and their evolution, but above all the innovations brought to the preceding disciplines by new and more organic laws. This is a prevalently synchronic approach, horizontal, and a mostly formal analysis. Very common in Anglo-Saxon scholarship, especially American, this approach has placed particular attention on the issue of international agreements about assets, and the role of UNESCO: The former having become, especially since WWII, the most incisive tools in terms of intervention and in the end representing the most comprehensive legal framework; the latter being the entity which, precisely for its institutional duties, occupies a central place in the organization and praxis of safeguarding ${ }^{1}$.

\footnotetext{
${ }^{1}$ Blake J., International Cultural Heritage Law (Oxford: Oxford University Press 2015); Ciampi A., The Protection of Cultural Heritage: International Instruments and Italian Legislation, (Giappichelli, Torino 2014); Francioni F., \& GORdLEY J., ENFORCING InTERNATIONAL CUlTuRAL Heritage LaW (Oxford: Oxford University Press 2013); Labadi S., Unesco, Cultural Heritage and Outstanding Universal Value: Value-Based Analyses of the World Heritage and Intangible Cultural Heritage Conventions, (Lanham Md.: Altamira Press 2013); Borelli S., \& Lenzerini F., Cultural Heritage, Cultural Rights, Cultural Diversity: New Developments in International Law, (Leiden:
} 
A second field is connected to the interests of those scholars who, in the fields of political and social science, observe the development of models of the various "meso-politics", that is, the politics of a sector or particular problem, over time. In this sense, next to others, the field of cultural and environmental assets has determined the maturation of a strong interest in politological modelling, which, while certainly lacking the character of a differentiated interest which considers the diverse variables which enter into play to determine the outcomes of a certain political choice, nevertheless certainly has the merit to propose interesting interpretations above all through the use of comparison of the different national experiences realized ${ }^{2}$.

Natural attention to the question of cultural assets is also given by those scholars, belonging to a third, final sector of research, who come from a background in art history, or to a lesser degree, from technical disciplines relating to the management of museums, libraries and archives, who examine cultural assets as a natural field of action and election.

Meanwhile, still quite rare, both in Italy and abroad, are those studies which address the question of the politics of management of cultural and environmental assets from a historical point of view, observing both the legislative and institutional evolution and the evolution in the field of political and cultural debate, to identify the social and political forces, the actors and the dynamics which influence the relationships, which have carried out an effective and concrete action of intervention in this field ${ }^{3}$. It may perhaps be considered an exception, in this frame, the development of a vein of studies of administrative history which has focused attention instead on the internal dynamics of the apparatus of management, such as the

Nijhoff 2012); Langfield M., Logan W., \& Craith M. N., Cultural Diversity, Heritage AND Human Rights (London-New York: Routledge 2010); Stefano M. L., DAVIS P., \& CORSANE G., Safeguarding Intangible Cultural Heritage (Woodbridge: The Boydell Press 2012); Forrest C., International Law and the Protection of Cultural Heritage (London-New York: Routledge 2010); SMith L., \& AKagawa N., InTANGiBle Heritage (London-New York: Routledge 2009); AbdulQuawi Y., STANDARD-SetTing IN Unesco (Paris, Nijhoff, Leiden: Unesco 2007); Silverman H., \& Ruggles D. F., Cultural Heritage and Human Rights (New York: Springer 2007).

${ }^{2}$ BobBio L., Le Politiche dei Beni Culturali in Europa (Bologna: Il Mulino 1992); Cofrancesco G., I Beni Culturali: Profili di Diritto Comparato ed InTERNAZionale (Roma: Istituto Poligrafico e Zecca Dello Stato 1999).

${ }^{3}$ Guerzoni G., Cultural Heritage and Preservation Policies: Notes on the History of the Italian Case, Economic Perspectives on Cultural Heritage (Hutter M., \& Rizzo I., eds., Basingstoke-New: York Macmillan 1997); For the French Case See CATONI M. L., Il PATRIMONio Culturale IN Francia (Milano: Electa 2007); For the German Case See Crane S., Collecting ANd Historical CONSCIOUSNESS IN EARLy NineteEnTH-CENTURy Germany (Ithaca, London: Cornell University Press 2000). A very important contribution to a general overview about the matter of cultural heritage is given by the volumes published by, or about, National Trust's activity, both in Great Britain and in the United States. 
Superintendents and regulatory authorities - which in Italy has acquired a certain importance, following the French example of the study of the "réelinstitutionell". But this is, in truth, an exception, because on the contrary, the majority of the studies carried out so far come in large part from the field of legal science. One may also consider the new interest towards cultural assets demonstrated by economic scholars through the conviction, increasingly demonstrated in the frame of the current perspectives of economic globalization and the crisis of the role of nation states in the European and international economy, that a sufficient development of investments in the field of cultural assets can be an important response to the problem of new mechanisms of development.

Thus it seems meaningful to present the results of research dedicated to reconstructing the process of the formation, construction and organization of a Ministry for Cultural and Environmental Assets in Italy, as an expression of the development of an awareness, which passes through public opinion and the national political debate for about thirty years, following 1945, and which reclaims many of the elements already having emerged in the first part of the 20th century and even prior in the first forty years following Italian unification.

This allows us in fact to look at the field from a new, different point of view, focusing attention on a protectionist movement which, formed in the context of the European and international movement spanning the late 19th and early 20th centuries, was characterized specifically by the presence of several particular elements determined by specific historical conditions. But, it is also the useful lenses through which to understand both the point of arrival of this debate and the institutional, political, and social forms taken on by this particular public sector in Italy, also based on the outcomes of other experiences in Europe. Finally, a comprehensive evaluation of the outcomes of this process helps to underline the opening of a series of new issues that would remain relevant in the following period, and which still appear relevant today in the new European outlooks.

\section{THE FOUNDATION OF THE MINISTRY FOR CULTURAL AND ENVIRONMENTAL Assets: A POINT OF ARrival, A TURNING POINT}

The institution of the Italian Ministry for Cultural and Environmental Assets - created through the legislative act $\mathrm{n}^{\circ} 657$ of December 14, 1974was the last step in the long phase of debate and theoretical reflection, and legislative intervention, which had begun in 1945. In this sense, this act may be considered both a point of arrival along the path undertaken in those 
policies of protection which began in the period immediately following the Unification of Italy, but also a shift destined to open new prospects in this field. Significantly, this act came to pass precisely in the phase of the most intense social, political and cultural transformation that Italy had experienced in the framework of European and Western economic expansion. And, no less significant, the act came at the heart of the debate about the prerogatives and competencies regarding cultural asset management which the Regions of Italy acquired after their founding in 1970.

When searching for the historical roots of this important moment of Italian Political history, and in particular of the history of management of cultural assets, the fundamental elements can be traced back to the emergence of the Italian protectionist movement: a phenomenon which spanned the late 19th and early 20th century, that is, on the cusp of the opening of a new era marked by industrialization and the advent of modern mass society, including in Italy. This phenomenon corresponded fully with the development of protectionist movements in all European countries, and many countries beyond, as a fulfillment and expression of the process of construction of the national territorial State. In fact, as in other places, in Italy, the attention to the problem of safeguarding culture grew on the one side as a result of the full awareness of the governmental leadership of the need to create a "symbolic stage" for the newly created nation in order to solidify its identity. In other words, this was one of the characteristic aspects of the process of nation building in the late 19th century, and at least in part in the "invention of a national Italian tradition". On the other hand, it was the realization of a process of affirmation of mass society, connected to the first industrial boom, which marked the turning of the century, and which rendered liberal élites aware of the risks brought by modernization, and thus the necessity to defend historical treasures located throughout the territory.

Deriving from these premises are several consequent characteristics that mark the experience of cultural safeguarding in Italy-differentiating it in part with respect to that of other countries - and which merit consideration since within them are contained the roots of several choices that defined the nature of the new Ministry and the structure given to it. The first element that should be underlined is the fact that, the protectionist movement was a political and cultural movement that concerned a limited group of men from Italian politics and culture, representatives of the liberal

\footnotetext{
${ }^{4}$ Halbwachs M., Les Cadres Sociaux de la Memoire (Paris-La Haye: Mouton 1976).

${ }^{5}$ Hobsbawm E. J., \& RAnger T., The Invention of Tradition (Cambridge: Cambridge University Press 1984).
} 
governing class of the early 20th century, with a particular personal sensibility to this issue: The principle examples being Giovanni Rosadi, from Florence and Luigi Rava, from Ravenna, drafters of the first law for safeguarding approved in $1909^{6}$. In second place, it was a movement that, only very slightly involved political parties for several important reasons: in the early 20th century, there were not mass political parties in Italy, and then - after 1922 - Italy experienced an authoritarian party in power; and because, in the post WWII period, the prevalence of ideologies determined scarce attention towards specific issues and content of political action in favor of comprehensive visions of society and of the world: Catholic, Liberal-democrat and Atlantistic for the Christian Democrats; Marxist, Social-Communist and Pro-Soviet for the Communist Party and to a certain degree also the Socialist Party. From these first two elements, there derives also a third characteristic which merits attention: the fact that, the protectionist movement was, especially at the beginning, a movement which tied itself to an elitist and literary vision of cultural and environmental heritage: Prior to and during the period of Fascism, this patrimony was protected in part for its inherent beauty, following a typically universalistic configuration deriving from the French Enlightenment, but also above all as a part of the Nation's history, acquiring the suggestions of Romanticism and German Idealism: Examples of this stance are the case of the pine woods of Ravenna, put under protection in 1905 given their connection to Dante and thus a symbol of national history and literature, and also in the laws of 1909 and 1939 proposed and approved by the Fascist Minister of National Education, Giuseppe Bottai. In this sense, it was also a movement which was not able to define a harmonious relationship between the old and the new: unlike, for example, English society-in which the problem of protection of cultural and environmental assets had been addressed in a timely manner in the context of the modern industrial city-in Italy, there was always a separation between historical memory and modernity.

It was a movement that was not able to define the problem of the harmonious relationship between safeguarding public interest and defence of the liberal principle of private property: Protective laws, viewed as detrimental to the principal of personal freedom and private property, were hotly contested by associations of owners of ancient property, or by the owners themselves. During the transition to the Republic, after Fascism, this controversy was evident in the debate which took place in the Constituent Assembly of Italy over the issue of whether to insert the principle of

\footnotetext{
${ }^{6}$ Balzani R., Per le Antichita' e le Belle Arti: La Legge No 364 Del 20 Giugno 1909 e L'Italia Giolittiana, (Bologna: Il Mulino 2003).
} 
protection - as some delegates desired, in particular a young Catholic exponent such as Costantino Mortati-in the fundamental law of the Italian State, or exclude it, in defence of private property, as other members desired, significantly a historic exponent of the tradition of liberalism and the rule of law, Vittorio Emanuele Orlando.

Finally, it was a movement which took place within Parliament and public institutions, but which saw emerge from the start the important role of private associations: both in the early 20th century-with the birth of many associations for "the defence of monuments" - and in the post WWII era with the foundation, in 1955, of "Italia Nostra" (Our Italy), the principal association for protection of heritage, constructed on the model of the "National Trust" in England, and which - despite being armed with much more limited means of intervention-carried out an important role of lobbying in Parliament and in the government.

In the aftermath of WWII, these elements returned in large part to frame the debate and the action of the Italian political class in terms of protection, above all when the issue of cultural assets became central to Italian politics through the economic and social transformations introduced by the "economic miracle" of the 1950s and 1960s, which affected the landscape with a vast process of construction and urban development. The issue of cultural assets emerged with several specific characteristics which in large part retraced the original premises: A specific, relevant role was played by private associations - in particular "Italia Nostra"-compared to the indifference of political parties. It was "Italia Nostra"- the association founded in 1955 by a group of intellectuals to denounce the ruin of the Roman urban fabric that would have followed the approval of the new general master plan for the capital - which took up the principle battles against urban decay and destruction of cultural assets: the battle for the historic Appia Antica roadway, the urban master plan of Milan, for Venice. Consequently, there remained an element of elitism which strongly marked the Italian protectionist sensibility: The principal actors were always limited groups and figures who intervened from daily newspapers and opinion papers. Leonardo Borgese, for example, and above all Antonio Cederna, a caustic and inflexible critic of Italian ills in the pages of the "Mondo" newspaper of Mario Pannunzio. Another characteristic was the strong contrast between defenders of the old and those who maintain that, the old must be inserted in the new: This is a particularly evident element when debate opens about the management of historic city centres with the creation, in 1960, of the National Association for historic centres with the Gubbio Charter. 
Meanwhile, a partially new element was the role of emergencies in raising awareness towards the problems of cultural and environmental assets. This issue began to enter the agenda of political parties above all following several catastrophic events that damaged cultural assets: above all the Florence flood of 1966-which struck for example the treasures of the National Library - the landslide in Agrigento in 1967, the disaster of Venice, and so on. It was in this period, in fact that, the issue became politically significant and intertwined, in the reflections of the great forces of the masses and especially after 1968, with the affirmation of a new generational subjectivity - the youth and university movement-a growing environmental sensibility which shifted attention towards the environment as an element to save from the risks of industrialization and pollution.

\section{THE FoundATION OF THE MiNISTRY AND THE ROLE OF GIOVANNI SPADOLINI}

As confirmation of the significant role of individual actors in the maturation of the Italian protectionist conscience and of the action carried out in the legislative seat, it is worthwhile noting that, the creation of a Ministry for Cultural and Environmental Assets appears as the result of a definitive acceleration impressed upon the debate in progress by Giovanni Spadolini, exponent at the forefront of the Partito Repubblicano Italiano (Republican Party of Italy), nominated Minister of Cultural Assets in the Moro-La Malfa government in December 1974. In fact, after the previous attempts of the Christian Democrat Camillo Ripamonti, it was Spadolini who promoted and obtained the foundation of a Ministry which centralized and coordinated the administration of protection. And, contrary to the thesis supported by several coeval opinions, his efforts were not driven by a personal ambition marked by vanity, but due to the conviction that, it was necessary to endow this delicate branch of Italian administration with "a stronger characterization, including financial autonomy, for a field which, prior to coming into existence, carried the weight of an enormous burden of unresolved problems, requests and expectations which with difficulty, according to the judgement of some exponents of the world of politics and culture, would have been satisfactorily resolved with an Executive Order"7. But it was precisely the fact of founding a Ministry by Executive Orderthe first case in Italian History-which represented at the same time an element of rupture with a legislative and institutional praxis which had been

\footnotetext{
${ }^{7}$ Bruno I., La Nascita Del Ministero Per I Beni Culturali ed Ambientali. Il Dibattito Sulla Tutela, 13 (Milano: Il Filarete 2011).
} 
followed up to that point, but also to consent to overcome difficulties and even fears which had up to that point contributed to strand the proposal in the "quicksand" of parliamentary debate. If anything, it should be underlined that, Spadolini was able to obtain such a quick, incisive result not only thanks to his authority as a political leader, helped above all by a decentralized position with respect to the principle mass forcesmembership in the Republican Party, a small but battle-hardened formation of a "third force" which carried with it the tradition of the Democratic Unification of Italy and the most fervent Anti-Fascismo - but also due to his personal prestige as a scholar and publicist confirmed by the role acquired in the Italian university system when appointed as the first chair of Contemporary History, founded in 1960 at the Istituto Cesare Alfieri di Firenze, and through the lengthy experience in journalism which had brought him to the direction of the "Corrieredella Sera" newspaper, traditionally the voice of the most advanced Italian bourgeoisie ${ }^{8}$.

As Andrea Emiliani has underlined, "The position of Giovanni Spadolini was very attentive, detailed in every decision. A cultured reader and a tenacious collector of bibliographies, he possessed the true advantage of active idealismo, that is, to be able to accept vast methodological propositions from different schools of thought, recasting them within a doctrine which had above all the sense of liberty and a strong sense of quality. Thus, if his reasoned opposition to the pressing hypothesis of decentralization was nurtured by historical experience (the only one existing, in truth), it is nevertheless true that, Spadolini reasoned in the modernity of a conscious political model. This model referred, with little delay, to the most modern and engaged period of development of this country, and thus to the years of Giovanni Giolitti, as was typical of Spadolini's general system of thought"'?

Not by chance, the foundation of the Ministry was preceded by a long, intense period of study and preparation which saw the involvement of some of the most eminent figures of Italian culture and politics, engaged in the subject of cultural assets. The archive that Spadolini himself gathered and constructed over the course of his professional life, today transferred to the namesake foundation with beautiful headquarters in Piandei Giullari near Florence, in this sense signals about all the awareness of the urgency that,

\footnotetext{
${ }^{8}$ Ceccuti C., Spadolini Storico e Uomo di Governo. Bibliografia Degli Scritti di Storia Moderna e Contemporanea, Degli Scritti e Discorsi Politici (1980-1985), (Ceccuti C., ed., Firenze: Le Monnier 1985).

${ }^{9}$ Testimony of Andrea Emiliani in Borsi F., Venti Anni dei Beni Culturali, Nuova Antologia (2196/Ottobre-Dicembre 1995).
} 
the situation of Italian cultural assets necessitated at the beginning of the 1970s: the ample press file that Spadolini implemented in 1972-73 highlights in particular the deplorable conditions to which artistic and monumental assets above all fell victim. Then, in the course of the preparatory works, three ample dossiers were collected to offer an ample base of materials. The first was a Report on the protection of cultural assets - dated September 13, 1971-consigned to the Secretary of the Permanent Commission for Public Education in the Chamber of Deputies, justified by the Need for a restructuring of the Administration responsible for protecting Italian cultural assets, recently highlighted by the numerous press articles following the accentuation of the degrade of various important monuments, significant works of art, and of entire historical complexes. ${ }^{10}$

Towards this end, a work group consisting of experts and actors in the fields of Preservation and Art History had been assembled-Pietro Bellini, Vincenzo Cappelletti, Gianfilippo Carettoni, Elena Croce, Paola Della Pergola, Giuseppe Donato, Giovanni Ioppolo, Giuliana Limiti-which had prepared a survey distributed to 117 entities of Preservation and Museum Documentation, Archivists and Library Sciences. From the 70 responses received, above all there emerged the shared conviction for the need to institute an autonomous ministerial entity, which would uncouple the functions of protection from the coordination which up to that point had been attributed to the Ministry of Public Education. Particular attention was given to the tasks of systematic protection and preservation, to museums, to restoration, and a unanimous request for expanding economic resources and the training of personnel.

Among the preparatory materials, Spadolini and his collaborators could make use of the project prepared by his predecessor at the Ministry, Camillo Ripamonti. This project-consisting of only seven articles-prefigured a centralized ministerial structure to which were conferred attributions concerning:

(1) Antiquities and Fine Arts, Academies and Libraries, Natural and Environmental treasures, under competency of the Ministry of Public Education and institutions under special statute which depended on said Ministry;

(2) Archives, under competency of the Ministry of the Interior;

(3) The National Musical and Film Archives, along with information

\footnotetext{
${ }^{10}$ Ricerca Sulla Tutela dei Beni Culturali-Documento di Lavoro, 6 CAMERA DEI DEPUTATI, UfFICIO STUDI, LegisLAZIONE ED INCHIESTE PARLAMENTARI (Settembre 13, 1971) (data apposta in corsivo a matita), Fondazione Spadolini-Nuova Antologia, Archivio di Giovanni Spadolini, Ministero per i Beni Culturali e per l'ambiente, Faldone 1, f. 3.
} 
services related to cinema, television and print media, concerning assets of artistic and historical worth, under competency of the Presidency of the Council of Ministers;

(4) The determination, in concert with the Ministry of Public works, regulated by Article 9 of the Decree of the President of the Republic January $15,1972 \mathrm{n}^{\circ} 3$, of directions for coordination of protection, under the artistic or environmental profile, of historic centres and archeological areas, natural or ecological sites, to this end protected or protectable in conformity to existing laws;

(5) Vigilance, and relative functions, of entities, institutions, and associations, already exercised by those administrations indicated by numbers $1,2,3^{11}$.

A significant element was the plan to institute a National Council as an advisory body of the Ministry, designated to give opinions on all issues concerning not only interventions for protection but also the functional organization of the Ministry: said Council, composed of 72 members, would have been through appointment, comprising also representatives of the Regions, of the Autonomous Provinces of Trento and Bolzano, and local entities. Finally, the Government was charged with preparation of a redefinition of the entire administrative apparatus of protection, and in particular, of the network of Superintendents, according to criteria of streamlining and decentralization.

Alongside the project of Ripamonti and the work of the Commission for Education of the Chamber of Deputies, among the papers of Spadolini can be found a third file containing a report entitled.

French cultural life and role of the State, accompanied by two brief missives by the historian Paolo Ungari, in that moment exponent of the Republican party and active collaborator of Spadolini himself. The file began with a consideration of the positive evolution of French cultural life, especially in the previous two decades, in particular with such an increase in finances as to make possible a much better management of services and consequently a growth in the economic stimulus deriving from cultural activities. Nevertheless, the file then focused on the importance of the French Ministry of Cultural Affairs, created by executive decree on July 24, 1959 under the government of De Gaulle, and entrusted respectively to André Malraux from 1959 to 1969, to Edmond Michelet from 1969 to 1971, and to Jacques Duhamel from 1971 to 1973 . This entity was structured as a central directorate on which depended the National Fund for Cultural

\footnotetext{
${ }^{11}$ Progetto Ripamonti, Fondazione Spadolini-Nuova Antologia, Archivio di Giovanni Spadolini, Ministero per i Beni Culturali e per l'ambiente, Faldone 1, f. 1.
} 


\section{POLICY AND LEGISLATION FOR CULTURAL 239}

Innovation and alongside of which was the National Centre for Cinematography, in a position of autonomy. Under the Ministry were eight services with competencies for the various sectors of cultural activity and on the functioning of the Ministry itself-Department of General Administration, Department di Architecture, System of Archives, System of Museums, System of the Theatres of Opera, Ballet and Classical Music, Department with competency for Theatres and Centres for literary culture, Services of artistic creation, Services of architectural studies and plastic arts. To the Ministry reported also five operative services: The General Inspectorate for administrative services, the General Delegation for expositions, the Services of study and research, the Service for excavations and antiquities, the General Catalog of historical monuments and artistic treasures of France. Thus it was a highly centralized structure, which followed in large part the traditional arrangement of French prefectorial administration, although not to be ignored was the role played-also in a decentralized function - of the "Maisons de la culture" which is established throughout the French territory starting in the $1970 \mathrm{~s}^{12}$.

\section{THE FOUNDATION OF THE MINISTRY FOR CULTURAL AND ENVIRONMENTAL AsSETS: THE EXECUTIVE ORDER N ${ }^{\circ} 657$ OF 14 DECEMBER 1974}

The foundation of the Ministry was ultimately determined by the presentation and approval of the Executive Order $n^{\circ}$ 657of December 14, 1974. Article 1 dictated the fundamental regulation:

Thus is founded the Ministry for Cultural and Environmental Assets, henceforth denominated as the Ministry.

Bringing the not insignificant innovation, compared to the first documents drafted, of the diction "per" (for) and not "dei" (of) to indicate, as has been opportunely underlined, the commitment that, Spadolini himself wanted to represent "in favor of Italian cultural and environmental assets" ". The lean Article 1 was intended to emphasize the political import of the foundation of the Ministry, an act which in the intentions of Spadolini was aimed at overcoming the complex issues which had marked the subject in the 113 years of the Italian State. The second article in fact attributed to the Ministry, the competency for "protection and promotion" with the other important innovation of conceiving the management of assets not only as

\footnotetext{
${ }^{12}$ French Cultural Life and the Role of the State, Fondazione Spadolini-Nuova Antologia, Archivio di Giovanni Spadolini, Ministero per I Beni Culturali e per l'Ambiente, Faldone 1, f. 2.

${ }^{13}$ Bruno I., La Nascita Del Ministero Per I Beni Culturali Ed Ambientali ..., cit., page 21.
} 
passive but also as active in its significant economic implications. Furthermore, to the Ministry was given competency for the diffusion of art and culture through the direction and coordination of initiatives both domestically and abroad, except for competencies of the Ministry of Foreign Affairs and in coordination with the same. It devolved also to the new Ministry the competencies formerly of the Ministry of Public Education concerning Antiquities and Fine Arts, Academies and Libraries and the diffusion of Culture, those of the Ministry of Internal Affairs concerning archives, and functions relative to the "safety" of cultural assets, with reference to inspections and penal actions handled by the Justice Department and Police. Furthermore, it established a harmonious synergy between the Regions and Local Entities and also attributed competencies on the management of territory in concert with the Ministry of Public Works. By contrast, the Ministry was removed from the expected participation in the Interministerial Committee for Economic Planning, related to those special projects for Southern Italy which involved matters of its competency. At the top of the organization of protection, there was the Supreme Council for Antiquities and Fine Arts and the Supreme Council for Academies and Libraries, which however would become consultative bodies of the Ministry, and which were presided over by the Ministry for Cultural Assets. Finally, until the new Ministry was definitively organized, the personnel of the competent Offices were to be "commanded" by the new body and "in relation to particular needs" the Ministry could - in concert with the Ministry of Labour - confer particular professional roles to experts outside the State Administration or to university professors, up to a maximum of five spots.

As evidence of the significance which the foundation of the Ministry was acquiring, and of the particular significance of the foundation created by Executive Order, the presentation in the Senate-December 19, 1974of the proposed bill to be made into Law was accompanied by a lively debate not without elements of criticism, which had in any case already emerged during the period of debate which had accompanied the presentation of three other bills related to the Ministry: The first under signature of the Minister of Public Education Oscar Luigi Scalfaro in concert with that of the Treasury Giovanni Malagodi and the Keeper of the Seals Guido Gonella, on March 20, 1973; the other two respectively by the liberals Vittorio Badini Confalonieri-on April 12, 1974-and Salvatore Valitutti-on May 17 of the same year. These were all projects which largely advanced the contents and profiles of the final project. After the report delivered by Spadolini himself in the session of January 9, 1975, 


\section{POLICY AND LEGISLATION FOR CULTURAL 241}

underlining the urgency of the measure based on the existent lengthy debate and the deplorable conditions of cultural assets, the first critical elements emerged through the socialist Achille Corona, who-after having expressed strong support for the initiative of Spadolini-nevertheless highlighted perplexities regarding the instrument of the Executive Order and also of the contents: above all regarding the contrast between an acceptation of protection in terms of landscape and aesthetics and an arena for discussion of the problem of industrial development such that, there was a risk to create a "semblance" of protection lacking real instruments for effective intervention.

Criticism of the hastiness of the foundation was expressed by the liberals and above all, in harsh interventions by the communists Roberto Maffiolettiand Rodolfo Bollini. In general, the Executive Order, if not considered as a sort of "bill placed under the axe of the 60 day deadline" according to constitutional dictates, as evidenced by Valitutti-was however considered a sort of typical "Italian hash" also for the fact that, it lacked the necessary and urgent conditions required by Article 77, and thus it raised questions of constitutional legitimacy.

No less severe criticisms were levelled during the phase of work of the Commission, installed, by decision of Spadolini, according to the law January $29,1975 \mathrm{n}^{\circ} 5$ which conferred to the Government the proxy for actualization of the Decree ${ }^{14}$, and successively, during the debate of the installed parliamentary Commission, again following the terms of the law, in October of the same year. Above all, while considering as positive the framework of the draft decree prepared by the Commission, which tended to maintain the balance of the administrative structure hinging on the Superintendencies, but which accentuated the scientific and technical

\footnotetext{
${ }^{14}$ Members included the Under Secretary for Cultural Assets Alberto Spigaroli, the Head of Cabinet and Head of Legislative Office of the same Ministry Michele Savarese and Umberto Tarin; the General Director of Antiquities and Fine Arts Salvatore Accardo; the General Director of the State Archives Marcello Del Piazzo; the General Director of the Academies and Libraries Beniamino Macaluso; Giulio Carlo Argan, Guglielmo De Angelis D'ossat e Massimo Pallottino as members of the Supreme Council of Antiquities and Fine Arts; Giorgio Vigni, Central Inspector of the Direction itself; Gino Barbieri as member of the Supreme Council of the State Archives; Giovanni Cassandro, constitutional judge, as member of the Supreme Council of the Academies and Libraries; representing the Ministryof Public Education Romano Cammarata and Pasquale De Rosa, The Organizational Office; Bixio Cappucci, representative of the Ministry of the Treasury; Emilio Dacunto for Internal Affairs; Vittorio Raimondi for the Presidency of the Council of Ministries; the representatives of the Regions Augusto Barbera (Emilia-Romagna), Vito Bozzi (Puglia), Carlo Fontana (Lombardia), Mario Schinaia (Office of Regions of thePresidency of the Council); the union representatives Vincenzo De Luca e Francesco Ricci; along with Franco Borsi, Fabio Merusi, Mario Pacelli, Umberto Pototschnig, Alberto Predieri, Fabio Roversi Monaco, Silvano Tosi, Massimo Severo Giannini (who was elected President of the Commission) in the role of experts.
} 
profiles, and streamlined the entire branch by subdividing the Ministry in five Central Offices - environmental assets, historical and artistic assets, archaeology, academies, libraries, and audiovisual holdings, and the central institutes - two limits were underlined. The first called for greater harmonization of the relationships with the periphery of the territory and above all for the competencies-considered limited-conferred to the Regions, to the Autonomous Provinces and to local entities, also in relation to the Decrees which in the meantime had infact begun to transfer powers from the central government to the Regions through the decrees of actualization of the Regions with Ordinary Statute: This was the majority opinion expressed by regional representatives in the Commission and from others, marked by the ample correspondence between Regional Presidents and Council members and the Ministry, along with the meeting of the national association of Italian Municipalities, which took place in Florence on September 24, 1975 under the guidance of the Mayor of Florence Elio Gabbuggiani. The second emerged above all from the opinions of the labour unions of specific categories, who strongly expressed support for an expansion of the body, of the strengthening of guarantees given to it, and especially in favor of the stabilization of the career positions and of salaries.

It was on the basis of these opinions that - after the meetings of the restricted Committee held in the month of November, the Commission sent to the Ministry a concise report which underlined the adequacy and balance reached between technical and political functions; it pointed out, if anything, the expediency to limit the recourse to the proxy law and put forth several more specific proposals for the creation of a National Institute for Graphics and the study of forms of autonomy for local museums; it proposed to maintain unaltered the institute for photo printing, bookbinding and restoration of the State Archives and to limit the expansion of the body and career progressions.

The Ministry for Cultural and Environmental Assets was ultimately instituted by the Decree of the President of the Republic of Dicembre 3, $1975 \mathrm{n}^{\circ}$ 805. At the top of the structure, a National Council for Cultural Heritage was instituted, composed of: representatives for each of the Ministries of Foreign Affairs, Budget and Economic Planning, the Interior, Public Works, Agriculture and Forestlands, Public Education, and Industry, Commerce \& Handicrafts, along with a representative of the office of the Minister for Scientific Research; a representative for each Region with a regular statute, and one for each Region with special statute and for each autonomous Province; eighteen university professors from archaeological, historical-artistic-architectural, literary, and library science disciplines; 
eighteen representatives of scientific personnel of the Administration, of six representatives of the remaining personnel of the Administration, of ten representatives of the Municipalities designated by the National Association of Italian Municipalities; four experts nominated by the Minister and two experts in sacred art, also nominated by the Minister. In addition to scientific, technical and administrative management, The National Council had the tasks of coordination and organization, carried out through the sectorial structure in which it was divided. Towards the periphery of the territory, the structure stretched to the network of Superintendents, and each region saw the founding of a Regional Committee for Cultural Assets with the task of coordination.

Thus, the foundation of the Ministry represented the point of arrival of a debate and engagement that had occupied political forces, social actors, and exponents of the scientific community for more than a century, and which, after the interruption determined by the Second World Warrecovered momentum in the circumstances of the great transformations taking place in Italian society and territory. From this moment forward, the further evolution of the politics of management of cultural assets, up to the 1980s and 1990s, and until the new discipline introduced by the Code of 2004, would have to take into account this fundamental innovation, this essential point of reference.

\section{CONCLUSIONS}

Three considerations we can draw at the end of this analysis, conducted through the examination of the birth of the Ministry for Cultural and Environmental Heritage. We should note, of course, they are purely problematic conclusions: as Henri Irenée Marrou wrote in his masterpiece arounf historical knowledge in 1954, the only certainty of a historian may be to bring new questions and new problems.

The institution of a Ministry for Cultural and Environmental Heritage in Italy, between 1974 and 1975, was the result of a long period of debate started at the end of the Nineteenth Century, and developed along the whole Twentieth Century. It was the result of the emergence and development of a new consciousness of the relevance beauty acquired both at a cultural and political level.

It was, secondly, the result of the emergence of a new level of specialistic intellectuals breaking, especially during the $60 \mathrm{~s}$, the hegemony of the universal category of intellectual derived from the Enlightenment. Linked to the emergence of a new "urban matter" these new intellectuals- 
architects and urban planners above all-determined a new view and conceptualization of the relationship between ancient and modern in the organization of landscape and conservation of cultural heritage.

The institution of the Ministry was, to conclude, the point of arrival of a phase of analysis and reflection putting out new problems: Especially linked to the new role cultural heritage can play within the political debate and action, they represent the new challenges facing academic research and political actors for the present and the future. 